\title{
AKTIVITAS IMUNOGLOBULIN M (IgM) \\ EKSTRAK ETANOL KULIT BUAH KAKAO (Theobroma cacao L.) TERHADAP TIKUS PUTIH (Rattus norvegicus)
}

\author{
Vita Olivia Siregar, Rolan Rusli, Arsyik Ibrahim \\ Labotarium Penelitian dan Pengembangan Kefarmasian FARMAKA TROPIS Fakultas \\ Farmasi, Universitas Mulawarman, Samarinda, Kalimantan Timur \\ email: vitaoliviasiregar@gmail.com
}

\begin{abstract}
The research of Immunoglobulin $M$ (IgM) activity of Theobroma cacao peel extract has been done to 20 rats. The parameter is agglutination between serum of rats and antigen. Rats were grouped to 4 group, which are group of negative control and 3 groups as experiment groups those given by extract in 250, 500 and $700 \mathrm{mg}$ doses of rats. On the first day was given SDMK $2 \%$ by Intraperitonial and after 5 day the serum taken and tested. The data of agglutination then analyzed by Anova. The experiment showed that Theobroma cacao peel extract has activity as immunostimulant in $500 \mathrm{mg}$ doses of rats effective dose.
\end{abstract}

Keywords: Theobroma cacao peel extract, agglutination, immunostimulant, Immunoglobulin M (IgM)

\begin{abstract}
ABSTRAK
Penelitian Aktivitas Imunoglobulin M (IgM) Ekstrak Kulit Buah Kakao (Theobroma cacao L.) telah dilakukan terhadap 20 ekor tikus uji. Parameter yang diamati adalah terjadinya aglutinasi antara serum tikus yang telah diberi perlakuan dengan antigen. Tikus putih

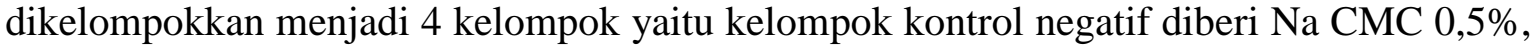
serta 3 kelompok uji yang diberikan ekstrak dengan konsentrasi 250, 500 dan 700 mg/200 $\mathrm{g}$ BB Tikus. Perlakuan secara per oral diberikan selama 5 hari. Pada hari ke-1 diinjeksikan Sel Darah Merah Kambing (SDMK) 2\% secara intraperitonial dan setelah perlakuan, yaitu hari ke-7 serum diambil dan dilakukan pengujian dengan metode titer antibodi. Data hasil pengamatan aglutinasi di analisis menggunakan Anova. Hasil penelitian menunjukkan bahwa ekstrak kulit buah Kakao memiliki aktivitas sebagai imunostimulan dengan dosis terbaik $500 \mathrm{mg} / 200 \mathrm{~g}$ BB tikus.
\end{abstract}

Kata kunci: Ekstrak Kulit Buah Kakao, Theobroma cacao L., IgM tikus putih, Hemaglutinasi, Imunostimulan

\section{PENDAHULUAN}

Sistem imun adalah semua mekanisme yang digunakan tubuh untuk mempertahankan keutuhannya terhadap bahaya yang dapat ditimbulkan berbagai benda asing. Imunitas mengacu pada kemampuan tubuh melawan/ mengeliminasi benda asing atau sel abnormal yang potensial berbahaya. Sistem pertahanan imun berperan penting dalam mengenali dan menghancurkan atau menetralisir benda-benda yang dianggap asing tersebut. Pertahanan imun ini terdiri dari sistem imun alamiah dan 
sistem imun spesifik. Sistem imun harus mampu melawan patogen intrasel maupun ekstrasel seperti virus, beberapa bakteri dan protozoa serta parasit. Jadi fungsi imun bersifat protektif terhadap tubuh.

Imunomodulator adalah suatu agen yang secara spesifik atau tidak spesifik meningkatkan atau mengurangi respon imun, yakni terdiri atas imunostimulan atau imunosupresan (Dorland, 2006). Imunostimulan adalah agen yang dapat merangsang respon imun. Sementara imunosupresan adalah agen yang dapat menekan respon imun.

Lingkungan sekitar terdapat banyak agen infeksius maupun non-infeksius atau agen-agen yang dapat memapar tubuh. Banyak faktor yang dapat melemahkan kekebalan tubuh selain dari yang telah disebutkan, seperti pola makan maupun pola hidup yang tidak sehat.

Kebanyakan masyarakat mengkonsumsi berbagai makanan maupun bahan yang dapat meningkatkan sistem pertahanan tubuh. Sumbernya dapat diperoleh secara langsung dari sayur/buah ataupun dalam bentuk produk jadi.

Tanaman Kakao (Theobroma cacao L.) terutama pada bagian bijinya diketahui memiliki berbagai senyawa fenolik yang beraktivitas dapat meningkatkan sistem imun. Selain itu tanaman ini juga bersifat sebagai antimikroba dan antioksidan, bahkan kandungan antioksidannya lebih tinggi dibanding teh dan anggur merah (Lee KW, Kim YJ, Lee HJ, \& Lee CY, 2003).

Kulit Kakao terdapat sekitar $70 \%$ dari seluruh bagian tanaman Kakao yang sejauh ini pemanfaatannya belum begitu besar. Menurut Sartini, et al., (2007), kulit Kakao memiliki potensi sebagai antioksidan dan antibakteri. Tidak menutup kemungkinan apabila kulit buah Kakao dapat memiliki aktivitas yang sama dengan bijinya, sehingga perlu dilakukan penelitian Aktivitas Imunoglobulin M (IgM) Ekstrak Etanol
Kulit Buah Kakao (Theobroma cacao L.) terhadap Tikus Putih (Rattus norvegicus).

\section{METODE PENELITIAN}

\section{Bahan}

Sampel yang diteliti adalah Kulit Buah Kakao (Theobroma cacao L.), bahan yang digunakan yaitu etanol $70 \%$, tikus putih sebagai hewan uji, larutan PBS (Phosphate Buffered Saline) pH 7,2 $\left(\mathrm{Na}_{2} \mathrm{HPO}_{4}, \mathrm{KH}_{2} \mathrm{PO}_{4}\right.$, dan $\left.\mathrm{NaCl}\right)$, EDTA, $\mathrm{Na}$ CMC 0,5\%, SDMK (Sel Darah Merah Kambing).

\begin{abstract}
Alat
Peralatan yang digunakan dalam penelitian ini adalah timbangan analitik, labu ukur, gelas kimia, Plat Tetes, mikro pipet, pipet volume, tabung reaksi, bejana maserasi, Rotary Evaporator (Buchi Labortechnik R-200), Inkubator, sentrifuge, tabung Eppendorf, Shaker, Spoid injeksi, Holder tikus, dan water bath.
\end{abstract}

\section{Pengumpulan Sampel}

Kulit buah Kakao (Theobroma cacao L.) yang digunakan adalah kulit dari buah yang telah matang dan berwarna kuning. Sampel diperoleh dari Jalan Sidrap Dalam, Kecamatan Teluk Pandan, Kabupaten Kutai Timur, Kalimantan Timur. Sampel yang digunakan berupa sampel kering, pengeringan dilakukan dengan cara menghindari kontak langsung dengan sinar matahari.

\section{Ekstraksi Kulit Buah Kakao (Theobroma cacao L.)}

Simplisia yang telah dirajang dimasukkan ke dalam bejana maserasi, lalu diberi cairan pengekstrak berupa etanol $70 \%$ sampai simplisia terendam secara sempurna. Proses ekstraksi berlangsung selama $5 \times 24$ jam, hasil ekstrak disaring menggunakan kertas saring lalu ditampung ke dalam wadah, kemudian simplisia direndam kembali 
dengan menggunakan pelarut etanol $70 \%$, proses ini diulangi hingga hasil ekstraksi berwarna bening. Hasil larutan ekstrak kemudian diuapkan menggunakan rotary evaporator hingga didapatkan ekstrak kental. Kemudian pelarut yang masih terkandung di dalam ekstrak kental diuapkan kembali dengan menggunakan waterbath hingga didapatkan ekstrak kering.

\section{Pembuatan Suspensi Sel Darah Merah kambing (SDMK 2\%)}

Darah kambing segar yang telah diberi EDTA disentrifugasi dengan kecepatan $3000 \mathrm{rpm}$ selama 10 menit. Lapisan atas berupa plasma dibuang dan lapisan bawah berupa endapan sel darah merah ditambahkan larutan PBS $\mathrm{pH}$ 7,2 sebanyak 3 kali volume endapan sel darah merah. Tabung dibolak-balik perlahan hingga homogen, lapisan atas yang jernih dibuang, prosedur ini diulangi hingga lapisan atas benar-benar jernih, sehingga lapisan bawah adalah suspensi SDMK 100\%. $2 \mathrm{~mL}$ suspensi SDMK $100 \%$ ditambahkan PBS ad 100 $\mathrm{mL}$, maka didapatkan suspense SDMK $2 \%$.

\section{Pengujian terhadap Hewan Coba}

Penelitian dilakukan terhadap 20 tikus putih (Rattus norvegicus) yang dibagi dalam 5 kelompok uji, kemudian diadaptasi selama 1 minggu.

SDMK $2 \%$ diberikan secara intraperitonial pada seluruh kelompok uji. Setelah 24 jam, 3 kelompok uji masingmasing diberi ekstrak kulit buah Kakao 250, 500 dan $750 \mathrm{mg} / 200 \mathrm{~g}$ BB Tikus, serta 1 kelompok uji diberi $\mathrm{Na} \mathrm{CMC}$ $0,5 \% 1 \mathrm{~mL}$ secara oral selama 5 hari berturut-turut.

24 jam setelah hari ke-5 perlakuan secara oral, pengambilan darah dilakukan. Pengambilan darah dilakukan melalui vena lateralis yang terdapat pada ujung ekor tikus hingga diperoleh sekitar $0,5 \mathrm{~mL}$ darah. Selanjutnya darah dibiarkan membeku selama 0,5-1 jam agar pemisahan serum sempurna. Kemudian disentrifugasi dengan kecepatan $3000 \mathrm{rpm}$ selama 10 menit. Bagian atas yang bening berupa serum diambil dan dipanaskan pada penangas suhu $56^{\circ} \mathrm{C}$ selama 30 menit. Setelah mencapai suhu ruang serum dapat diuji.

\section{Pengujian Imunoglobulin M (IgM) \\ Hemaglutinasi} Masing-masing serum dilakukan pengujian hemaglutinasi dengan penambahan antigen SDMK 2\%. Plat tetes pada kolom 2 hingga 10 (pengenceran 1/2, 1/4, 1/8, 1/16, 1/32, $1 / 64,1 / 128,1 / 256,1 / 512$, dan 1/1024) diberi PBS pH 7,2 masing-masing sebanyak $100 \mu \mathrm{L}$. pada kolom pertama diberi serum tikus sebanyak $200 \mu \mathrm{L}$, kemudian $100 \mu \mathrm{L}$ serum dari kolom pertama dimasukkan ke dalam kolom ke2, dihomogenkan, dari kolom ke-2 diambil $100 \mu \mathrm{L}$ dan dimasukkan ke dalam kolom ke-3, dihomogenkan, perlakuan yang sama hingga kolom terakhir, $100 \mu \mathrm{L}$ dari kolom terakhir dibuang. SDMK $2 \%$ sebanyak $100 \mu \mathrm{L}$ dimasukkan ke masing-masing kolom, hingga jumlah campuran tiap kolom sebanyak $200 \mu \mathrm{L}$. Setiap plat tetes kemudian diinkubasi pada suhu $37^{\circ} \mathrm{C}$ selama 1 jam dan dibiarkan selama 24 jam pada suhu ruang untuk dapat dilakukan pengamatan terjadinya aglutinasi. Data yang diambil ialah pengenceran tertinggi yang masih menunjukkan adanya aglutinasi. Selanjutnya, angka pengenceran tersebut ditransformasikan ke dalam rumus angka titer [2 log (titer)+1] agar dapat dilakukan analisis data.

\section{HASIL DAN PEMBAHASAN}

Pengukuran Imunoglobulin $\mathrm{M}$ (IgM) dilakukan dalam rentang waktu 5 sampai 7 hari. Saat antigen pertama kali masuk ke dalam tubuh, maka dalam jangka waktu 5-7 hari antibodi yang keluar adalah IgM. Dalam jangka waktu 
tersebut IgM berada maksimal pada darah dibandingkan dengan antibodi lainnya.

Aglutinasi dapat terbentuk karena reseptor pengikat antibodi terikat pada antigen membentuk jembatan antara 2 molekul antigen, terus-menerus mengikat hingga membentuk pola geometris kompleks 3 dimensi dengan ukuran besar hingga $>2 \mu \mathrm{m}$, sehingga aglutinasi akan terlihat.
Hasil menunjukkan bahwa dari seluruh dosis uji ekstrak kulit buah Kakao yang diujikan memiliki aktivitas sebagai imunostimulan dengan terjadinya peningkatan aglutinasi serum tikus yang mengandung IgM. Angka titer rata-rata tiap kelompok uji dapat dilihat pada Gambar 1.

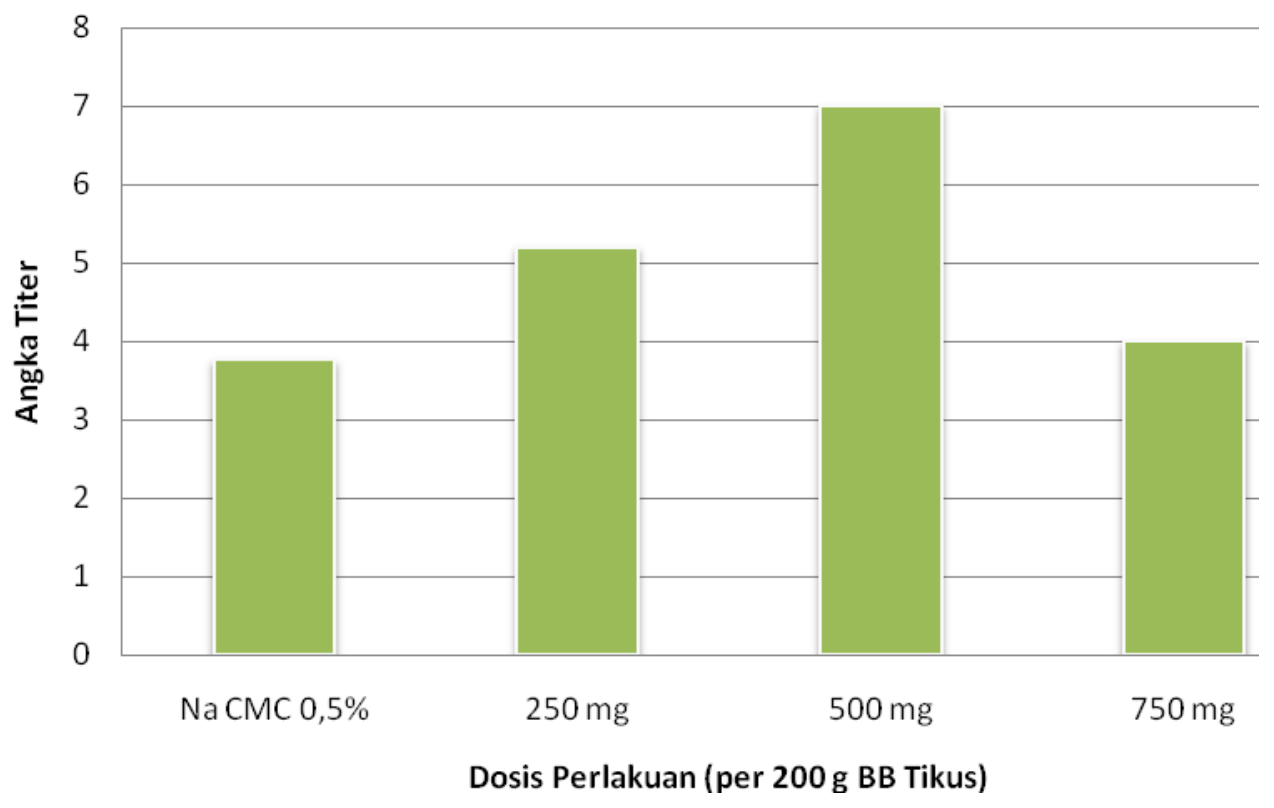

Gambar 1. Angka Titer rata-rata tiap kelompok pengujian

Gambar 1 menunjukkan angka titer sebenarnya pada tiap perlakuan, angka titer diperoleh dengan mengkonversi titer pengenceran ke dalam rumus $[2 \quad \log$ (titer)+1]. Titer pengenceran berbanding lurus dengan angka titer.

Perlakuan menggunakan NaCMC $0,5 \%$ menunjukkan aktivitas imunostimulan dengan rata-rata angka titer 3,76. Sementara ke-3 kelompok perlakuan lain menunjukkan adanya aktivitas imunostimulan yang lebih tinggi. Perlakuan Dosis ekstrak kulit buah Kakao dosis 250 mg/200 g BB Tikus menunjukkan hasil lebih tinggi dibandingkan dengan $\mathrm{Na}$ CMC $0,5 \%$ dengan rata-rata angka titer 5,2.
Sementara maksimal aktivitas aglutinasi terlihat pada dosis $500 \mathrm{mg} / 200 \mathrm{~g} \mathrm{BB}$ Tikus dengan rata-rata angka titer 7,0 dan kembali turun pada dosis $750 \mathrm{mg} / 200 \mathrm{~g}$ BB Tikus dengan rata-rata angka titer 4,0 .

Hasil analisis statistika dari 3 dosis ekstrak kulit buah Kakao yang diuji dengan kontrol negatif $\mathrm{Na} \mathrm{CMC} 0,5 \%$, menunjukkan bahwa $\mathrm{F}$ hitung dengan nilai 47,51 lebih besar dari $\mathrm{F}$ tabel pada $5 \%$ maupun $1 \%$, maka terdapat perbedaan atau berbeda sangat signifikan. Ini menunjukkan bahwa semua perlakuan dosis uji memiliki aktivitas yang sama sebagai imunostimulan. Untuk mengetahui dosis terbaik ekstrak etanol kulit buah Kakao sebagai imunostimulan, 
perlu dilakukan uji lanjutan. Salah satu syarat untuk uji lanjutan adalah menghitung nilai koefisien keragaman. Nilai koefisien keragaman didapatkan sebesar 8,33\%, maka uji lanjutan dilakukan dengan uji Beda Nyata terkecil (BNT).

Hasil dari analisis BNT menunjukkan bahwa dosis terbaik sebagai imunostimulan adalah 500 mg/200 g BB Tikus, karena merupakan dosis yang mampu memberikan aktivitas terbaik dan sangat signifikan.

\section{KESIMPULAN}

Berdasarkan hasil penelitian dapat disimpulkan bahwa ekstrak kulit buah Kakao (Theobroma cacao L.) memiliki aktivitas imunostimulan dengan dosis terbaik $500 \mathrm{mg} / 200 \mathrm{~g}$ BB Tikus.

\section{DAFTAR PUSTAKA}

1. Departemen Kesehatan \& Kesejahteraan sosial. 2001. Inventaris Tanaman Obat Indonesia (I) Jilid 2. Badan Penelitian dan Pengembangan kesehatan. Jakarta

2. Dorland, W.A. Newman. 2006. Kamus Kedokteran Edisi 29. Penerbit Buku Kedokteran. Jakarta.

3. Lee, K.W., Kim, Y.J., Lee, H.J., Lee C.Y., 2003. Cocoa has more phenolic phytochemicals and a higher antioxidant capacity than teas and red wine. J Agric Food Chem. 51.(25). 7292-7295.

4. Othman, A., Ismail, A., Ghani, N.A., Adenan, I., 2007. Antioxidant Capacity and Phenolic Content of Cocoa Bean. Food Chemistry. 100. 1523-1530.

5. Sartini. Djide, Natsir. Alam, Gemini. 2007. Ekstraksi Komponen Bioaktif dari Limbah Kulit Buah Kakao dan Pengaruhnya terhadap Aktivitas Antioksidan dan Antimikroba. Fakultas Farmasi Universitas Hasanuddin. Makassar.

6. Sudjana. 2005. Metoda Statistika. Penerbit Tarsito. Bandung. 